\title{
Neutral detergent fibre in piglet diets: digestibility, performance, and deposition of body nutrients
}

\author{
RAFAEL C. NEPOMUCENO ${ }^{1}$, PEDRO H. WATANABE ${ }^{1}$, EDNARDO R. FREITAS ${ }^{1}$, LUIZ E. \\ DE CARVALHO ${ }^{1}$, EMANUELA L. DE OLIVEIRA ${ }^{1}$, THALLES R. GOMES ${ }^{1}$, GERMANA C. \\ AGUIAR ${ }^{1}$, RAYSSA S. CANDIDO ${ }^{1}$, JORDÂNIA L. FERREIRA ${ }^{1}$ and ALINI M. VEIRA ${ }^{2}$ \\ ${ }^{1}$ Universidade Federal do Ceará, Departamento de Zootecnia, Avenida Mister Hull, \\ 2977, Campus do Pici, Bloco 807, 60455-900 Fortaleza, CE, Brazil \\ ${ }^{2}$ Universidade Estadual de São Paulo, Faculdade de Ciências Agrárias e Veterinárias, Via de \\ Acesso Paulo Donato Castelane, s/n, 14884-900 Jaboticabal, SP, Brazil
}

Manuscript received on July 23, 2015; accepted for publication on July 28, 2016

\begin{abstract}
A total 120 piglets with an average live weight of $7.00 \mathrm{~kg}$, weaned at 21 days, were used to evaluate the effect of neutral detergent fibre levels on the digestibility of nutrients and energy from the diets, productive performance, and the composition and rate of deposition of nutrients and energy in the bodies of piglets in the nursery phase. The animals were distributed according to a randomized-block design into five treatments, which consisted of neutral detergent fibre levels, with six replicates and four animals per plot. A quadratic effect was detected for the digestibility coefficients of nutrients and energy, feed intake and weight gain. The increase in fibre level promoted a linear increase in fat content in the carcass, blood, and body, whereas the energy in the carcass, organs, and body showed an inverse response. The results showed a quadratic effect on the nutrient deposition rate in the carcass, organs and body. In conclusion, the best digestibility of nutrients and energy from the diet is obtained with 10-11.5\% neutral detergent fibre, as higher weight gain and greater protein deposition in the body are achieved at neutral detergent fibre levels of $10.6 \%$ and $10.3 \%$, respectively.
\end{abstract}

Key words: dietary fibre, retention of nutrients, pigs, post-weaning.

\section{INTRODUCTION}

The definition of the maximum rate of deposition of nutrients in the carcass, during various pig-rearing phases, is an essential piece of information in determining the nutritional requirements necessary to maximize tissue growth in these animals.

Correspondence to: Rafael Carlos Nepomuceno

E-mail: rafael@zootecnista.com.br / rafael.zootecnista@ufc.br
However, determining the animals' nutritional and energy requirements is a difficult task, since the efficiency of use of the nutrients and energy for many physiological processes such as maintenance, growth, gestation, and lactation is variable, besides the fact that several other factors interfere with it, e.g., the weather, the muscle activity performed by the animal, and the chemical composition and energy concentration of diets. 
Thus, certain dietary components, such as the fibre fraction, may compromise the efficiency and use of dietary nutrients and energy, especially in the initial life stages of piglets, when their immune and digestive systems are still immature, with insufficient production of specific enzymes necessary for the digestion of plant ingredients. This becomes especially important when one considers the high nutrient requirement during this period (Aumaitre 2000, Hedemann et al. 2006). This situation may lead to an inflammatory response from the digestive tract, triggering diarrheal processes with consequent growth retardation and negative impacts on the performance of these animals.

In contrast, some research has suggested that the use of different sources of fibre in diets for newly weaned piglets may promote the maintenance of intestinal health and prevent diseases such as postweaning diarrhoea(Mosenthin etal.1999, Montagne et al. 2003, Budiño et al. 2010), however, data on the fibre requirement are scarce and contradictory. Whittemore et al. (2003) suggested that piglets in nursery phase should receive diets with 7 to $13 \%$ neutral detergent fibre (NDF), while Mateos et al. (2006) verified that NDF contents higher than 7.7\% in diets negatively affect production performance of newly weaned piglets.

The divergence in the research related to fibre level corroborate the hypothesis that there is an optimal level of fibre to be used in the diet for weanling pigs that do not compromise the digestion and absorption of diet nutrients, allowing the animals to achieve maximum performance.

Therefore, the concept of fibre-increase in piglet diets and its relationship with the rate of deposition of nutrients and energy in the animal's body must be well-defined so that it will be possible for the animal to make the best use of the dietary nutrients, as well as possible benefits derived from the fibre fraction of the diet.
In this context, it should be noted that dietary fibre, carbohydrate polymers with ten and more monomeric units that are neither digested nor absorbed in the human small intestine (Cummings et al. 2009), can be expressed in different forms, according to the diversity of analytical methods of isolation and quantification. Considering the different available methods to determine the fibrous components, those based on enzymatic digestion best express the dietary fibre content of feedstuffs (McCleary et al. 2012); however, a practical, applicable approach is to use the NDF method for the measurements of the insoluble cell wall materials which represent the fraction with the most pronounced negative impact on total tract digestibility and nutrient utilization. The method proposed by Van Soest and Wine (1967) to NDF is widely employed in animal feeding, as this variable is considered to be the datum with the best correlation with total dietary fibre content (Silva and Queiroz 2002), in addition to being present in the database of most animal-feed chemical composition systems (NRC 2012, Rostagno et al. 2011).

In the face of new methods of determination of fibrous fractions of foods and of the new concepts related to fibre, not only associated with the old definition as anti-nutritional factor, the current published studies with fibre in the swine feeding report data only sources of fibre assessments, without considering the effect of fibre level; whereas the researches that evaluate the fibre to weanling pigs are scarce and less conclusive. Thus, this research is the first to study the effects of fibre levels and determine the best level for weanling pigs' diets.

Given the above scenario, the objective of this study was to evaluate the effect of levels of NDF on the digestibility of dietary nutrients and energy; productive performance; and composition and rate of deposition of nutrients and energy in the body of piglets in the nursery phase. 


\section{MATERIALS AND METHODS}

The experimental procedures were approved by the Committee of Ethics on Animal Research of the Universidade Federal do Ceará, under protocol $n^{\circ}$. $55 / 2013$ of November 2013, and the experiment complied with the Ethical Principles of Animal Experimentation adopted by the Brazilian College of Animal Experimentation.

The experiment was conducted in the Pig Farming Section of the Department of Animal Science at the Universidade Federal do Ceará, using 120 castrated male piglets of the Topigs line, weaned at 21 days of age, and with an average live weight of $7.00 \pm 0.54 \mathrm{~kg}$, in the period of 21 to 42 days of age.

The animals were distributed according to a randomized-block design into five treatments, which consisted of various levels of neutral detergent fibre (NDF) $(8.5,10.5,12.5,14.5$, and $16.5 \%$ ), with six replicates per treatment and four animals per plot. The initial weights of the animals were the criterion adopted to form the blocks.

The piglets were housed in masonry sheds equipped with semiautomatic feeders, nipple drinkers, and side curtains, which were managed daily. Climatic variables were monitored by four data loggers distributed in the shed, $60 \mathrm{~cm}$ above the floor, where temperature and relative humidity were recorded in 10-minute intervals.

The chemical analyses of the feedstuffs were performed at the Animal Nutrition Laboratory of the Department of Animal Science of Universidade Federal do Ceará, where the dry matter (DM) and crude protein $(\mathrm{CP})$ contents were quantified according to AOAC (1990), and neutral detergent fibre (NDF) and acid detergent fibre (ADF) according to the methodology described by Van Soest et al. (1991). The results of the analyses showed 89.7\% DM, 8.2\% CP, 12.5\% NDF, and $2.3 \%$ ADF in corn; $90.6 \% \mathrm{DM}, 39.0 \% \mathrm{CP}, 18.5 \%$ $\mathrm{NDF}$, and $10.0 \% \mathrm{ADF}$ in soybean meal; $90.0 \% \mathrm{DM}$,
$33.0 \% \mathrm{CP}, 15.2 \% \mathrm{NDF}$, and 7.3\% ADF in wholefat extruded soybean; and 94.4\% DM, $14.8 \%$ $\mathrm{CP}, 38.1 \% \mathrm{NDF}$, and $28.2 \% \mathrm{ADF}$ in wheat bran. Depending on the similarity of the mean values for the ingredients recommended by Rostagno et al. (2011), the metabolisable energy, fat, calcium, phosphorus, sodium, amino acids, and starch values of the ingredients were utilized according to these same authors.

The experimental diets (Table I) were formulated to be isoenergetic and isonutritive, considering the nutritional requirements for piglets at 21-32 and 33-42 days of age, according to Rostagno et al. (2011). The wheat bran was the main source of fibre used to promote increased NDF level in the diets. During the entire experimental period, feed and water were available ad libitum.

To evaluate the digestibility of the nutrients and energy from the diet, one animal from each plot, represented by the average weight of the plot, was allocated to an individual stall in the period corresponding to the $33^{\text {rd }}$ and $40^{\text {th }}$ days of age and fed the experimental diets, according to the treatments designated at the outset. The digestibility coefficients were determined by the method of partial faeces collection, with the inclusion of $0.5 \%$ Celite $^{\circledR} 545$ in the diets, and using acid insoluble ash as a marker. The acclimation period was represented by the first two days, followed by five days for collection, in which approximately $200 \mathrm{~g}$ of faeces were collected from each animal, twice daily, and stored in plastic bags that were conditioned in a freezer at $-15{ }^{\circ} \mathrm{C}$. At the end of the collection period, the animals returned to their experimental units of origin.

Subsequently, the samples were homogenized and subjected to analyses of dry matter, crude protein, ether extract, mineral matter, and organic matter, according to AOAC (1990). Levels of neutral detergent fibre, acid detergent fibre, and hemicellulose were measured as well, with the proper corrections for the presence of starch, as 
TABLE I

Centesimal and nutritional composition of the experimental diets for piglets in the nursery phase.

\begin{tabular}{|c|c|c|c|c|c|c|c|c|c|c|}
\hline \multirow{3}{*}{ Ingredient } & \multicolumn{6}{|c|}{21 to 32 days of age } & \multicolumn{4}{|c|}{33 to 42 days of age } \\
\hline & \multicolumn{10}{|c|}{ Neutral detergent fibre level (\%) } \\
\hline & 8.50 & 10.50 & 12.50 & 14.50 & 16.50 & 8.50 & 10.50 & 12.50 & 14.50 & 16.50 \\
\hline Corn grain & 24.81 & 31.46 & 35.08 & 43.20 & 34.34 & 18.50 & 22.86 & 50.54 & 41.68 & 32.81 \\
\hline Soybean meal & 24.69 & 21.40 & 18.42 & 10.10 & 0.41 & 30.06 & 27.01 & 20.26 & 10.57 & 0.88 \\
\hline Full-fat extruded soybean & 0.00 & 0.00 & 0.00 & 5.76 & 15.23 & 0.00 & 0.00 & 1.49 & 10.96 & 20.43 \\
\hline Wheat bran & 0.54 & 5.19 & 10.69 & 15.02 & 24.15 & 0.00 & 5.29 & 4.11 & 13.23 & 22.36 \\
\hline Starch & 21.21 & 14.56 & 9.95 & 0.00 & 0.00 & 26.51 & 21.40 & 0.00 & 0.00 & 0.00 \\
\hline Corn gluten $60 \%$ & 8.00 & 8.00 & 8.00 & 8.00 & 8.00 & 8.00 & 8.00 & 8.00 & 8.00 & 8.00 \\
\hline Milk permeate powder & 1.50 & 1.50 & 1.50 & 1.50 & 1.50 & 1.50 & 1.50 & 1.50 & 1.50 & 1.50 \\
\hline Skim milk powder & 5.50 & 5.50 & 5.50 & 5.50 & 5.50 & 5.50 & 5.50 & 5.50 & 5.50 & 5.50 \\
\hline Sugar & 3.00 & 3.00 & 3.00 & 3.00 & 3.00 & 3.00 & 3.00 & 3.00 & 3.00 & 3.00 \\
\hline Soybean oil & 2.60 & 2.60 & 2.60 & 2.60 & 2.60 & 1.20 & 1.20 & 1.20 & 1.20 & 1.20 \\
\hline Monodicalcium phosphate & 1.83 & 1.76 & 1.69 & 1.62 & 1.50 & 1.54 & 1.47 & 1.46 & 1.34 & 1.22 \\
\hline Limestone & 0.85 & 0.88 & 0.92 & 0.95 & 0.99 & 0.92 & 0.96 & 0.98 & 1.02 & 1.05 \\
\hline Common salt & 0.56 & 0.56 & 0.56 & 0.55 & 0.55 & 0.44 & 0.43 & 0.42 & 0.43 & 0.43 \\
\hline Vitamin-mineral supplement* & 0.40 & 0.40 & 0.40 & 0.40 & 0.40 & 0.40 & 0.40 & 0.40 & 0.40 & 0.40 \\
\hline L-lysine $\mathrm{HCl}$ & 0.70 & 0.76 & 0.82 & 0.89 & 0.92 & 0.38 & 0.44 & 0.57 & 0.60 & 0.62 \\
\hline DL-methionine & 0.20 & 0.19 & 0.19 & 0.19 & 0.20 & 0.09 & 0.09 & 0.08 & 0.09 & 0.09 \\
\hline L-threonine & 0.24 & 0.26 & 0.28 & 0.30 & 0.31 & 0.09 & 0.11 & 0.14 & 0.15 & 0.16 \\
\hline L-tryptophan & 0.07 & 0.08 & 0.09 & 0.10 & 0.09 & 0.02 & 0.03 & 0.04 & 0.03 & 0.04 \\
\hline BHT & 0.01 & 0.01 & 0.01 & 0.01 & 0.01 & 0.01 & 0.01 & 0.01 & 0.01 & 0.01 \\
\hline Inert & 3.29 & 1.89 & 0.30 & 0.31 & 0.30 & 1.84 & 0.30 & 0.30 & 0.29 & 0.30 \\
\hline Total & 100.00 & 100.00 & 100.00 & 100.00 & 100.00 & 100.00 & 100.00 & 100.00 & 100.00 & 100.00 \\
\hline \multicolumn{11}{|c|}{ Calculated nutritional composition } \\
\hline Metabolisable energy $(\mathrm{kcal} / \mathrm{kg})^{\mathrm{a}}$ & 3325 & 3325 & 3325 & 3325 & 3325 & 3325 & 3325 & 3325 & 3325 & 3325 \\
\hline Crude protein $(\%)^{\mathrm{a}}$ & 19.56 & 19.56 & 19.56 & 19.56 & 19.56 & 20.56 & 20.56 & 20.56 & 20.56 & 20.56 \\
\hline Available phosphorus $(\%)^{\mathrm{a}}$ & 0.49 & 0.49 & 0.49 & 0.49 & 0.49 & 0.44 & 0.44 & 0.44 & 0.44 & 0.44 \\
\hline Calcium $(\%)^{\mathrm{a}}$ & 0.83 & 0.83 & 0.83 & 0.83 & 0.83 & 0.81 & 0.81 & 0.81 & 0.81 & 0.81 \\
\hline Digestible lysine $(\%)^{\mathrm{a}}$ & 1.42 & 1.42 & 1.42 & 1.42 & 1.42 & 1.30 & 1.30 & 1.30 & 1.30 & 1.30 \\
\hline Digestible met + cys $(\%)^{\mathrm{a}}$ & 0.79 & 0.79 & 0.79 & 0.79 & 0.79 & 0.73 & 0.73 & 0.73 & 0.73 & 0.73 \\
\hline Digestible threonine $(\%)^{\mathrm{a}}$ & 0.89 & 0.89 & 0.89 & 0.89 & 0.89 & 0.82 & 0.82 & 0.82 & 0.82 & 0.82 \\
\hline Digestible tryptophan $(\%)^{\mathrm{a}}$ & 0.26 & 0.26 & 0.26 & 0.26 & 0.26 & 0.23 & 0.23 & 0.23 & 0.23 & 0.23 \\
\hline Sodium $(\%)^{\mathrm{a}}$ & 0.27 & 0.27 & 0.27 & 0.27 & 0.27 & 0.22 & 0.22 & 0.22 & 0.22 & 0.22 \\
\hline Fat & 3.17 & 3.90 & 4.40 & 6.33 & 7.66 & 2.74 & 3.29 & 5.92 & 7.25 & 8.58 \\
\hline Starch & 38.78 & 38.24 & 37.87 & 35.02 & 31.75 & 39.95 & 39.54 & 37.19 & 33.91 & 30.63 \\
\hline $\mathrm{NDF}$ & 8.50 & 10.50 & 12.50 & 14.50 & 16.50 & 8.50 & 10.50 & 12.50 & 14.50 & 16.50 \\
\hline $\mathrm{ADF}$ & 3.45 & 3.80 & 4.15 & 4.45 & 4.70 & 3.70 & 4.05 & 4.41 & 4.66 & 4.90 \\
\hline Hemicellulose & 5.05 & 6.70 & 8.35 & 10.05 & 11.80 & 4.80 & 6.45 & 8.09 & 9.84 & 11.60 \\
\hline
\end{tabular}

*Vitamin A 1,500,000.00 IU, vitamin D3 450,000.00 IU, vitamin E 7,500.00 mg, vitamin K3 1,500.00 thiamine (vitamin B1) $250.00 \mathrm{mg}$, riboflavin (vitamin B2) $1,300.00 \mathrm{mg}$, pyridoxine (vitamin B6) $375.00 \mathrm{mg}$, vitamin B12 5.000,00 mg, niacin 7.500,00 mg, calcium pantothenate $4,500.00 \mathrm{mg}$, folic acid $150.00 \mathrm{mg}$, Biotin $22.50 \mathrm{mg}$, choline $68,000.00 \mathrm{mg}$, iron 12,500.00 mg, copper 5,250.00 mg, manganese 8,750.00 mg, zinc $26,250.00 \mathrm{mg}$, iodine $350.00 \mathrm{mg}$, selenium $75.00 \mathrm{mg}$, antioxidant $1,000.00 \mathrm{mg}$. ${ }^{\mathrm{a}}$ Rostagno et al. (2011). 
described by Van Soest et al. (1991). Gross energy was measured by combustion in an adiabatic bomb calorimeter (Model 1242, Parr Instruments Co. USA). Levels of acid-insoluble ash were measured by digestion in $4 \mathrm{~N}$ hydrochloric acid. Samples were then burned in a muffle furnace according to the methodology proposed by Van Keulen and Young (1977). To measure the performance variables, the animals and diets were weighed at the beginning and end of each phase. The feed leftovers were collected and quantified daily to calculate the intake. Average daily weight gain and average daily feed intake data were obtained as the differences in weighting. Feed conversion was calculated as the ratio between feed intake and weight gain.

At 42 days of age, one animal from each plot, represented by the average weight of the plot, together with a control group composed of four newly weaned piglets of the same line, at 21 days of age, with an average weight of $7.09 \mathrm{~kg}$, were sacrificed by stunning and complete bleeding, to determine body chemical composition and nutrient deposition rate. The blood was collected in plastic bags and weighed. All organs, including the empty digestive and urinary tracts, accessory glands, reproductive organs, heart, liver, spleen, lung, kidneys, and perirenal fat were removed, emptied, and weighed. The carcass, consisting of head, hair, paws, and nails, was sawn in half in the longitudinal direction, and the halves were weighed individually. Separately, the left half-carcasses, organs, and blood were packed and frozen at $-15^{\circ} \mathrm{C}$ until processing.

Subsequently, the half-carcasses and organs were cut with a band saw and ground in an industrial meat grinder. After homogenization, a sample of each fraction was collected and frozen $\left(-15^{\circ} \mathrm{C}\right)$. Samples of carcass, organs, and blood were analysed for dry matter, crude protein, ether extract, and mineral matter according to AOAC (1990) and energy by combustion in an adiabatic bomb calorimeter (Model 1242, Parr Instruments
Co. USA). To determine levels of crude protein, samples had previously been defatted in a hexanereflux system in a Soxhlet extractor for 8 hours.

Based on the results of the chemical analyses, the composition of the different body parts (carcass, blood, organs, and body) was calculated and corrected as a function of each part of the respective animal, at slaughter.

The daily rates of deposition of crude protein, ether extract, mineral matter, water, and energy in the carcass and organs were obtained according to the following formula:

Deposition rate $=\frac{(\text { final content in } \mathrm{g} \text { or kcal })-(\text { initial content in } \mathrm{g} \text { or kcal })}{\text { number of days }}$

The body deposition rate was defined as the sum of the parts.

The statistical analysis was performed on the Statistical Analysis System (SAS Institute 2001). To establish the curve that best described the behaviour of the data, regression analyses were performed, considering levels of neutral detergent fibre in the diets as the sources of variation.

\section{RESULTS AND DISCUSSION}

The average ambient temperature during the experimental period was $28.23{ }^{\circ} \mathrm{C}$, with maximum and minimum temperatures of $33.3{ }^{\circ} \mathrm{C}$ and 25.0 ${ }^{\circ} \mathrm{C}$, respectively. The average relative humidity of the air was $62.4 \%$. The average temperatures were above the ideal thermal comfort range for weaned piglets $\left(22\right.$ to $\left.24{ }^{\circ} \mathrm{C}\right)$ kept at relative air humidity conditions of $50-70 \%$, but lower than the critical threshold $\left(35^{\circ} \mathrm{C}\right)$, which ensured an appropriate thermal environment for the expression of the animals' productive potential, according to Hannas (1999).

In the analysis of the digestibility coefficients (Table II), a quadratic effect of dietary NDF level was observed on the digestibility of all nutrients. The best digestibility coefficients of dry matter, organic matter, and mineral matter were estimated 
TABLE II

Digestibility coefficients of nutrients and energy from diets containing different levels of NDF for piglets in the nursery phase.

\begin{tabular}{|c|c|c|c|c|c|c|c|c|c|}
\hline \multirow{2}{*}{ Nutrient } & \multicolumn{5}{|c|}{ Neutral detergent fibre level (\%) } & \multirow{2}{*}{$\begin{array}{l}\mathrm{CV} \\
(\%)^{1}\end{array}$} & \multirow{2}{*}{ P-value } & \multirow{2}{*}{ Equation } & \multirow{2}{*}{$\mathrm{R}^{2}$} \\
\hline & 8.5 & 10.5 & 12.5 & 14.5 & 16.4 & & & & \\
\hline & \multicolumn{9}{|c|}{ Digestibility coefficient (\%) } \\
\hline Dry matter & 88.48 & 91.55 & 90.07 & 82.07 & 75.60 & 1.82 & 0.0001 & $y=-0.4325 x^{2}+8.9828 x+44.636$ & 0.89 \\
\hline Mineral matter & 84.63 & 89.17 & 85.55 & 68.55 & 50.37 & 6.08 & 0.0001 & $y=-1.1009 x^{2}+22.931 x-30.426$ & 0.92 \\
\hline Organic matter & 95.92 & 97.44 & 96.00 & 89.24 & 81.09 & 2.32 & 0.0001 & $y=-0.4610 x^{2}+9.5746 x+47.855$ & 0.91 \\
\hline Crude protein & 92.61 & 96.22 & 94.09 & 83.49 & 67.33 & 5.11 & 0.0001 & $y=-0.8946 x^{2}+19.097 x-5.2325$ & 0.87 \\
\hline Ether extract & 99.63 & 99.80 & 99.82 & 99.57 & 99.37 & 0.09 & 0.0001 & $\mathrm{y}=-0.0191 \mathrm{x}^{2}+0.4382 \mathrm{x}+97.294$ & 0.81 \\
\hline Neutral detergent fibre & 84.52 & 92.24 & 89.86 & 74.49 & 60.31 & 6.41 & 0.0001 & $y=-1.0145 x^{2}+22.053 x-28.752$ & 0.90 \\
\hline Acid detergent fibre & 72.84 & 88.93 & 86.78 & 62.42 & 35.94 & 9.33 & 0.0001 & $y=-1.9156 x^{2}+42.871 x-151.87$ & 0.91 \\
\hline Hemicellulose & 95.45 & 94.33 & 91.54 & 80.21 & 70.60 & 3.10 & 0.0001 & $y=-0.4557 x^{2}+8.2008 x+58.76$ & 0.94 \\
\hline Energy & 94.32 & 96.29 & 94.22 & 84.10 & 74.48 & 2.99 & 0.0001 & $y=-0.5579 x^{2}+11.354 x+38.389$ & 0.93 \\
\hline
\end{tabular}

${ }^{1} \mathrm{CV}$ - coefficient of variation.

at NDF levels of $10.4 \%$. For the crude protein, ether extract, and energy, the estimated levels of 10.7 , 11.5, and $10.2 \%$ NDF were, respectively, those which provided the best use of these nutrients. For the fibre fraction, the highest digestibility coefficients of NDF, ADF, and hemicellulose were estimated at NDF levels of 10.9, 11.2, and 9.0\%, respectively.

The reduction in the digestibility of the nutrients with the increase in dietary NDF, on average after $11 \% \mathrm{NDF}$, is in agreement with literature reports (Wenk 2001, Högberg and Lindberg 2004a, b, Len et al. 2009a, b) and may be associated with the adverse effects of this fraction in the feeding of pigs. The greater presence of cellulose and lignin in diets with higher levels of fibre is responsible for increasing the indigestibility, because these structures are resistant to enzymatic and microbial degradation and acid hydrolysis in the gastrointestinal tracts of pigs (Theander et al. 1989, Johnston et al. 2003). Furthermore, Wenk (2001) reported that high fibre content impairs the digestion and absorption of nutrients because this fraction acts as a physical barrier, preventing the digestive enzymes from accessing the internal content of plant cells.

Another physiological impact of diets with high fibre content is the loss of epithelial cells by mucosal desquamation, with a consequent increase in the rate of cell turnover (Hedemann et al. 2006), implying impairment of the brush border structure, which consequently negatively affects the digestion, absorption, and metabolism of nutrients in pigs and also causes an imbalance in energy expenditure, as calories are redirected from other functions to recovery of the mucosal surface. According to Jørgensen et al. (1996), the depreciation of digestibility caused by the inclusion of fibre is a result of the peristaltic action and reduced transit time in the small and large intestines, in addition to an increment of endogenous nitrogen, resulting from the secretions of digestive juices (Mosenthin et al. 1994).

However, it should be noted that there was an improvement in the digestibility coefficient of the nutrients with an increase in the dietary NDF level from 8.5 to approximately $10-11 \%$, indicating that newly weaned piglets need a minimum amount of fibre in their diet. According to literature reports 
(Mateos et al. 2006), this presence of fibre is necessary to ensure the normal motility of the gastrointestinal tract and time of exposure of the cud to the digestive processes for the digestibility of the organic matter not to be compromised and consequently compromise the digestibility of nutrients and energy.

The performance assay (Table III) revealed a quadratic effect of dietary NDF level on the feed intake and weight gain of animals in aged 2132 days, with the best results estimated for both variables at the level of $11 \%$ NDF. A quadratic effect was also observed on weight gain in the period of 21 to 42 days of age, whose best result was estimated at the level of $10.6 \% \mathrm{NDF}$.

Considering that the amount of nutrients and energy available for basal metabolism is directly related to the rate of weight gain, it can be stated that the performance results reflect the effects of NDF levels on the digestibility of dietary nutrients. This fact is evidenced by the similarity in the behaviour of curves and in the estimates for the maximum performance and digestibility of dry and organic matters, protein and energy. Thus, the increased fibre level in the diets until 10.6\% NDF resulted in a higher amount of nutrients available for absorption and protein metabolism; these were converted to animal body tissue, resulting in greater weight gain. However, the increasing of the amount of fibre in the diet from this level caused gradual reduction of digestibility of nutrients and energy which negatively affected weight gain due to the lower supply of nutrients.

Estimates of the best levels of NDF in the diet for piglet performance differ, in part, from those reported by researchers. Mateos et al. (2006) did not find any impairment on the performance of piglets when they were fed diets containing $6 \%$ NDF. However, Högberg and Lindberg (2004a) observed that the increase from 10.5 to $21.5 \% \mathrm{NDF}$ resulted in greater weight gain by weaned piglets. Schiavon et al. (2004), in turn, observed a decrease in the weight gain of piglets fed a diet in which the inclusion of beet pulp resulted in $18.5 \%$ NDF. The discrepancy in the results for the effects of the fibre fraction of the diet on the performance of piglets may be associated with the physiological effects caused by the chemical and physical characteristics as well as the degree of lignification and the amounts of feedstuff included as a fibre source (Wenk 2001).

The increase in the level of NDF resulted in alterations in the chemical composition of the piglets' body, with an observed linear increase in the fat content in the carcass $\left(y=0.13 x+10.5\right.$ and $\left.\mathrm{R}^{2}=0.83\right)$,

TABLE III

Average daily feed intake (ADFI), average daily weight gain (ADWG), and feed conversion (FC) of piglets fed different levels of neutral detergent fibre.

\begin{tabular}{|c|c|c|c|c|c|c|c|c|}
\hline \multirow{2}{*}{ Variable } & \multicolumn{5}{|c|}{ Neutral detergent fibre level (\%) } & \multirow{2}{*}{$\mathrm{CV}(\%)^{1}$} & \multirow{2}{*}{ Regression } & \multirow{2}{*}{ P-value } \\
\hline & 8.5 & 10.5 & 12.5 & 14.5 & 16.5 & & & \\
\hline \multicolumn{9}{|c|}{21 to 32 days of age } \\
\hline ADFI (kg) & 0.180 & 0.185 & 0.203 & 0.157 & 0.141 & 17.95 & Quadratic $^{3}$ & 0.0006 \\
\hline ADWG (kg) & 0.113 & 0.117 & 0.129 & 0.087 & 0.073 & 29.98 & Quadratic $^{4}$ & 0.0005 \\
\hline $\mathrm{FC}(\mathrm{kg} / \mathrm{kg})$ & 1.760 & 1.718 & 1.595 & 1.814 & 2.020 & 20.48 & $\mathrm{NS}^{2}$ & 0.0566 \\
\hline \multicolumn{9}{|c|}{21 to 42 days of age } \\
\hline ADFI (kg) & 0.311 & 0.311 & 0.315 & 0.287 & 0.271 & 15.30 & NS & 0.0671 \\
\hline ADWG (kg) & 0.259 & 0.264 & 0.269 & 0.232 & 0.210 & 16.54 & Quadratic $^{5}$ & 0.0029 \\
\hline $\mathrm{FC}(\mathrm{kg} / \mathrm{kg})$ & 1.224 & 1.201 & 1.172 & 1.237 & 1.325 & 12.86 & NS & 0.1373 \\
\hline
\end{tabular}

${ }^{1} \mathrm{CV}$ - coefficient of variation; ${ }^{2} \mathrm{NS}$ - not significant; ${ }^{3} \mathrm{y}=-0.0019 \mathrm{x}^{2}+0.0421 \mathrm{x}-0.0423$ and $\mathrm{R}^{2}=0.82 ;{ }^{4} \mathrm{y}=-0.0016 \mathrm{x}^{2}+0.0351 \mathrm{x}-$ 0.0684 and $\mathrm{R}^{2}=0.84 ;{ }^{5} \mathrm{y}=0.0017 \mathrm{x}^{2}+0.0359 \mathrm{x}+0.0761$ and $\mathrm{R}^{2}=0.93$. 
blood $\left(\mathrm{y}=0.11 \mathrm{x}+8.5552\right.$ and $\left.\mathrm{R}^{2}=0.84\right)$, and body ( $\mathrm{y}$ $=0.12 \mathrm{x}+8.9976$ and $\mathrm{R}^{2}=0.85$ ), because the elevation of the NDF level in the diets was accompanied by an increase in fat which was incorporated into the animal body due to high coefficient of digestibility of this nutrient. In contrast, the total energy in the carcass $(\mathrm{y}=$ $-220.7 x+18817$ and $\left.R^{2}=0.90\right)$, organs $(y=-29.40 x$ +1708.8 and $\left.\mathrm{R}^{2}=0.97\right)$, and body $(\mathrm{y}=-258.38 \mathrm{x}+$ 21282 and $R^{2}=0.92$ ) showed the opposite response, decreasing linearly.

Although the results of the proportion of total fat and total energy in the body of piglets may seem contradictory, the same can be explained by the methodology used, which correlated percentage each chemical component and the gross energy value, determined in samples of the fraction of the body (carcass, blood, organs and body) with weight of each body part of the respective animal body, at slaughter. Thus, while animals fed with higher NDF levels exhibited bodies with a higher proportion of fat, these also had lower body weight, reflecting lower weight gain, which explains the reduction in total energy of the piglet body. It is also necessary to consider that high-fibre diets are, in general, accompanied by a greater caloric increment coupled with a lower rate of efficiency of digestive processes, resulting in greater energy expenditure and a lower organic matter gain rate in the tissues, leading to a lower concentration of body energy.

A quadratic effect was observed on the rates of deposition of nutrients and energy in various body

TABLE IV

Effect of level of neutral detergent fibre on the rates of deposition of nutrients in the bodies of piglets aged 21 to 42 days.

\begin{tabular}{|c|c|c|c|c|c|c|c|c|c|}
\hline \multirow{2}{*}{ Parameter } & \multicolumn{5}{|c|}{ Neutral detergent fibre level (\%) } & \multirow{2}{*}{$\begin{array}{l}\mathrm{CV} \\
(\%)^{1}\end{array}$} & \multirow{2}{*}{ P-value } & \multirow{2}{*}{ Regression } & \multirow{2}{*}{$\mathrm{R}^{2}$} \\
\hline & 8.5 & 10.5 & 12.5 & 14.5 & 16.5 & & & & \\
\hline \multicolumn{10}{|c|}{ Carcass } \\
\hline Water (g/day) & 121.03 & 127.38 & 129.08 & 95.32 & 90.14 & 28.72 & 0.0003 & $y=-0.3365 x^{2}+6.8849 x-9.9433$ & 0.82 \\
\hline Protein (g/day) & 23.70 & 25.46 & 26.33 & 15.20 & 13.55 & 36.48 & 0.0009 & $y=-1.0451 x^{2}+21.436 x+16.297$ & 0.82 \\
\hline Fat (g/day) & 3.78 & 4.65 & 5.46 & 3.25 & 2.78 & 56.89 & 0.0042 & $y=-0.1015 x^{2}+2.3674 x-8.9374$ & 0.75 \\
\hline $\begin{array}{c}\text { Mineral } \\
\text { matter(g/day) }\end{array}$ & 2.35 & 1.75 & 2.14 & 1.04 & 1.19 & 50.89 & 0.0001 & $y=-0.1515 x+3.588$ & 0.70 \\
\hline $\begin{array}{c}\text { Energy (kcal/ } \\
\text { day) }\end{array}$ & 182.79 & 217.20 & 180.33 & 149.17 & 130.37 & 32.34 & 0.0063 & $y=-1.7987 x^{2}+36.323 x+13.358$ & 0.83 \\
\hline Water (g/day) & 42.78 & 43.70 & 40.86 & 42.23 & 35.02 & 28.72 & 0.0001 & $y=-0.2152 x^{2}+4.5299 x+19.634$ & 0.82 \\
\hline Protein (g/day) & 5.98 & 6.26 & 5.77 & 5.96 & 4.84 & 37.23 & 0.0009 & $y=-0.0382 x^{2}+0.8252 x+1.7158$ & 0.83 \\
\hline Fat (g/day) & 0.25 & 0.39 & 0.37 & 0.54 & 0.35 & 56.89 & 0.0042 & $y=-0.0083 x^{2}+0.225 x-1.0743$ & 0.65 \\
\hline $\begin{array}{l}\text { Mineral matter } \\
\text { (g/day) }\end{array}$ & 0.62 & 0.61 & 0.54 & 0.61 & 0.54 & 50.89 & 0.0001 & $y=-0.0078 x+0.6818$ & 0.45 \\
\hline $\begin{array}{l}\text { Energy (kcal/ } \\
\text { day) }\end{array}$ & 61.89 & 66.56 & 64.80 & 58.99 & 46.84 & 30.71 & 0.0063 & $y=-0.673 x^{2}+14.94 x-16.395$ & 0.97 \\
\hline \multicolumn{10}{|c|}{ Body } \\
\hline Water (g/day) & 163.80 & 171.08 & 169.94 & 137.55 & 125.17 & 23.16 & 0.0001 & $y=-1.2603 x^{2}+25.966 x+35.931$ & 0.91 \\
\hline Protein (g/day) & 29.67 & 31.72 & 32.11 & 21.16 & 18.38 & 27.66 & 0.0005 & $y=-0.3747 x^{2}+7.7101 x-8.2275$ & 0.86 \\
\hline Fat (g/day) & 4.03 & 5.03 & 5.83 & 3.79 & 3.14 & 44.49 & 0.0038 & $y=-0.1098 x^{2}+2.5924 x-10.012$ & 0.79 \\
\hline $\begin{array}{l}\text { Mineral matter } \\
\text { (g/day) }\end{array}$ & 2.98 & 2.36 & 2.68 & 1.65 & 1.74 & 34.06 & 0.0001 & $y=-0.1592 x+4.2698$ & 0.75 \\
\hline $\begin{array}{l}\text { Energy (kcal/ } \\
\text { day) }\end{array}$ & 244.68 & 315.51 & 245.13 & 208.15 & 177.20 & 28.53 & 0.0022 & $y=-3.0385 x^{2}+63.848 x-60.888$ & 0.74 \\
\hline
\end{tabular}

${ }^{1} \mathrm{CV}$ - coefficient of variation. 
parts, except for mineral matter, which decreased linearly as the NDF level increased (Table IV). In the carcass, the best rates of deposition of water, protein, fat, and energy were estimated at the NDF levels of $10.3,10.2,11.7$, and $10.1 \%$, respectively. In the organs, however, the diets with $10.5,10.8$, 13.6, and $11.1 \%$ NDF provided a greater daily deposition of water, protein, fat, and energy, respectively. On the other hand, improved rates of body deposition of water, crude protein, fat, mineral matter, and energy were estimated, respectively, in diets containing $10.3,10.3,11.8,8.5$, and $10.5 \%$ NDF.

The curves of the rates of deposition of water, protein, fat and energy in the carcass and body displayed a similar response to that shown by the curve of the respective coefficients of digestibility and weight gain of the piglets, in which levels below and above the range between 10.3 and $11.8 \%$ NDF compromised the deposition of nutrients in the animal, associated with the level at which the nutrients provided by the diets were best used.

Lipid deposition rates were influenced by the fat content of the diets, which was increased by the increased inclusion of full-fat extruded soybean as the NDF level was increased. However, it should be considered that the efficiency of use of the lipid fraction of the diets was not compromised at NDF levels greater than $11.5 \%$ of the diets. It was also observed that the deposition of fat in the organs was prioritized, which agrees with the allometric study conducted by Davies and Pryor (1977), which indicated that the deposition of fat in the body varies with time. This process occurs at a faster pace for the internal fat, which is the fat within the abdominal and pelvic cavities, and peritoneal fat, followed by the subcutaneous and intermuscular fat deposits.

The quadratic response shown by the energy deposition curve in the body had its best result estimated for diet with $10.5 \% \mathrm{NDF}$, near from the maximum point of weight gain, estimated for diets containing $10.6 \% \mathrm{NDF}$ and between the best rates of deposition of protein and fat. This may be correlated with the improved relationship between assimilated dietary nutrients and the higher energy balance of the metabolic processes required for growth, because the efficiency of energy utilization in swine is determined by the deposition of protein and fat, with a cost of deposition of $1.12 \mathrm{kcal} / \mathrm{g}$ of protein and $7.83 \mathrm{kcal} / \mathrm{g}$ of fat (Ewan 1991).

\section{ACKNOWLEDGMENTS}

The authors thank Banco do Nordeste do Brasil (BNB) for the financial support provided for this research project; Coordenação de Aperfeiçoamento de Pessoal de Nível Superior (CAPES), for the fellowship grant; and the Universidade Federal do Ceará (UFC) for providing the use of the infrastructure required for the study.

\section{REFERENCES}

AOAC - ASSOCIATION OF OFFICIAL ANALYTICAL CHEMISTS. 1990. Official methods of analysis. $15^{\text {th }}$ ed., Washington, DC, $1078 \mathrm{p}$.

AUMAITRE LA. 2000. Adaptation and efficiency of the digestive process in the gut of the young piglet: consequences for the formulation of a weaning diet. Asian Australas J Anim Sci 13: 227-242.

BUDIÑO FEL, CASTRO JÚNIOR FG AND OTSUK IP. 2010. Adição de frutoligossacarídeo em dietas para leitões desmamados: desempenho, incidência de diarreia e metabolismo. Rev Bras Zootec 39: 2187-2193.

CUMMINGS JH, MANN JI, NISHIDA C AND VORSTER HH. 2009. Dietary fibre: an agreed definition. Lancet 373: 365-366.

DAVIES AS AND PRYOR WJ. 1977. Growth changes in the distribution of dissectable and intramuscular fat in pigs. $\mathrm{J}$ Agr Sci 89: 257-266.

EWAN RC. 1991. Energy utilization in swine nutrition. In: Miller ER, Ullrey DE and Lewis AJ (Eds), Swine nutrition, Stoneham: Butterworth-Heinemann, Massachusetts, USA, p. 121-132.

HANNAS MI. 1999. Aspectos físiológicos e a produção de suínos em clima quente. In: Silva IJO (Ed), Ambiência e qualidade na produção industrial de suínos, Piracicaba: Fundação de Estudos Agrários Luiz de Queiroz, Piracicaba, BRA, p. 1-3. 
HEDEMANN MS, ESKILDSEN M, LAERKE HN, PEDERSEN C, LINDBERG JE, LAURINEN P AND KNUDSEN KE. 2006. Intestinal morphology and enzymatic activity in newly weaned pigs fed contrasting fibre concentrations and fibre properties. J Anim Sci 84: 1375-1386.

HÖGBERG AAND LINDBERG JE. 2004a. Influence of cereal non-starch polysaccharides and enzyme supplementation on digestion site and gut environment in weaned piglets. Anim Feed Sci Technol 116: 113-128.

HÖGBERG A AND LINDBERG JE. 2004b. Influence of cereal non-starch polysaccharides on digestion site and gut environment in growing pigs. Livest Prod Sci 87: 121-130.

JOHNSTON LJ, NOLL S, RENTERIA A AND SHURSON. 2003. Feeding by-products high in concentration of fibre to non-ruminants. In: Third National Symposium on Alternative Feeds for Livestock and Poultry Held in Kansas City. Proceedings... Kansas City, p. 1-26.

JØRGENSEN H, ZHAO X, KNUDSEN KE AND EGGUM BO. 1996. The influence of dietary fibre source and level on the development of the gastrointestinal tract, digestibility and energy metabolism in broiler chickens. $\mathrm{Br}$ J Nutr 75: 379-395.

LEN NT, HONG TTT, OGLE B AND LINDBERG JE. 2009a. Comparison of total tractdigestibility, development of visceral organs and digestive tract of MongCai and Yorkshire $\mathrm{x}$ Landrace piglets fed diets with different fibre sources. J Anim Physiol Anim Nutr 93: 181-191.

LEN NT, NGOC TB, OGLE B AND LINDBERG JE. 2009 b. Ileal and total tract digestibility in local (MongCai) and exotic (Landrace x Yorkshire) piglets fed low and highfibre diets, with or without enzyme supplementation. Livest Sci 126: 73-79.

MATEOS GG, MARTIN F, LATORRE MA, VICENTE B AND LAZARO R. 2006. The effect of inclusion of oat hulls in pig diets based on raw or cooked rice and maize. J Anim Sci 82: 57-63.

MCLEARY BV, DEVRIES, JW, RADER JI, COHEN G, PROSKY L, MUGFORD DC, CHAMP M AND OKUMA K. 2012. Determination of Insoluble, Soluble, and Total Dietary Fibre (CODEX Definition) by EnzymaticGravimetric Method and Liquid Chromatography: Collaborative Study. J AOAC Int 95: 824-844.

MONTAGNE L, PLUSKE JR AND HAMPSON DJ. 2003. A review of interactions between dietary fibre and the intestinal mucosa, and their consequences on digestive health in Young non-ruminant animals. Anim Feed Sci Technol 108: 95-117.

MOSENTHIN R, SAUER WC AND AHRENS F. 1994. Dietary pectin's effect on ileal and fecal amino acid digestibility and exocrine pancreatic secretions in growing pigs. J Nutr 124: 1222-1229.

MOSENTHIN RE, HAMBERECHT WC AND SAUER WC. 1999. Utilization of different fibres in piglet feeds. In: Garnsworthy PC and Wiseman J (Eds), Recent advances in animal nutrition, Nottingham: University Press, Nottingham, UK, p. 227-256.

NRC - NATIONAL RESEARCH COUNCIL. 2012. Nutrient Requirements of Swine, 11th rev. ed., Washington, DC: National Academic Press.

ROSTAGNO HS, ALBINO LFT, DONZELE JL, GOMES PC, OLIVEIRA RF, LOPES DC, FERREIRA AS, BARRETO LST AND EUCLIDES RF. 2011. Tabelas brasileiras para aves e suínos: composição de alimentos e exigências nutricionais, $3^{\mathrm{a}}$ ed., Viçosa: Editora UFV, 252 p.

SAS INSTITUTE. 2001. SAS/STAT software: changes and enhancements through release 8.02. Cary: Statistical Analysis System Institute, $1167 \mathrm{p}$.

SCHIAVON S, TAGLIAPIETRA F, BAILONI L AND BORTOLOZZO A. 2004. Effects of sugar beet pulp on growth and health status of weaned piglets. Ital J Anim Sci 337-351.

SILVA DJ AND QUEIROZ AC. 2002. Análise de alimentos: métodos químicos e biológicos. $3^{\mathrm{a}}$ ed., Viçosa: Editora UFV, $235 \mathrm{p}$.

THEANDER O, WESTERLUND E, AMAN P AND GRAHAM H. 1989. Plant cell wall and monogastric diets. Anim Feed Sci Technol 23: 205-225.

VAN KEULEN J AND YOUNG BA. 1977. Evaluation of Acid insoluble ash as a natural markers in ruminant digestibility studies. J Anim Sci 44: 282-287.

VAN SOEST PJ, ROBERTSON JB AND LEWIS BA. 1991. Methods for dietary fibre, neutral detergent fibre and nonstarch polysaccharides in relation to animal nutrition. $\mathrm{J}$ Dairy Sci 74: 3583-3597.

VAN SOEST PJ AND WINE RH. 1967. Use of detergents in the analysis of fibrous feeds. IV - Determination of plant cell-wall constituents. J Assoc Off Anal Chem 50: 50-55.

WENK C. 2001. The role of dietary fibre in the digestive physiology of the pig. Anim Feed Sci Technol 90: 21-33.

WHITTEMORE CT, HAZZLEDINE MJ AND CLOSE WH. 2003. Nutrient requirements standards for pigs. British Society of Animal Science, Penicuik, Midlothian, UK. 